\title{
Originals
}

\section{Induction of apoptosis by high proinsulin and glucose in cultured human umbilical vein endothelial cells is mediated by reactive oxygen species}

\author{
X.L.Du ${ }^{2,3}$, G.Z.Sui ${ }^{1}$, K.Stockklauser-Färber ${ }^{3}$, J. Weiß ${ }^{3}$, S.Zink ${ }^{3}$, B.Schwippert ${ }^{3}$, Q.X.Wu' ${ }^{2}$ D. Tschöpe ${ }^{3}$, P. Rösen ${ }^{3}$ \\ ${ }^{1}$ Department of Anatomy of Qing Dao Medical College, China \\ ${ }^{2}$ Department of Pathophysiology of Peking Union Medical College, China \\ ${ }^{3}$ Diabetes Research Institute at the Heinrich-Heine-University, Düsseldorf, Germany
}

\begin{abstract}
Summary There is much evidence that diabetes and hyperglycaemia contribute to the impairment of endothelial function and induce severe changes in the proliferation, the adhesive and synthetic properties of endothelial cells. Induction of apoptosis could represent one mechanism to prevent the new accumulation of those vascular defects and to allow generation of vascular endothelium. In this study, we demonstrate that high concentrations of glucose or proinsulin induce apoptosis in human umbilical endothelial cells by three independent methods (DNA fragmentation, fluorescence activated cell sorting analysis, and morphology). The number of apoptotic cells was increased by glucose $(30 \mathrm{mmol} / \mathrm{l}$ or proinsulin $(100 \mathrm{nmol} / \mathrm{l})$ from less than $10 \%$ to about $30 \%$. Activation of protein kinase C (PKC) largely prevented the induction of apoptosis, whereas inhibition of $\mathrm{PKC}$ further increased the number of apoptotic cells.
\end{abstract}

Similar changes as induced by glucose were also observed after incubation of the cells with the non-metabolisable 3-0-methylglucose. These findings indicate that hyperglycaemic conditions stimulate the induction of apoptosis in endothelial cells by a mechanism which is independent from the formation of diacylglycerol and the activation of PKC. The induction of apoptosis by the non-metabolisable glucose suggests that formation of oxygen derived radicals by autoxidative processes is involved and may lead to an activation of transcription factors such as nuclear transcription factor- $x \mathrm{~B}(\mathrm{NF}-x \mathrm{~B})$ transferring the activation signal into the nucleus and leading to changes in gene expression necessary for induction of apoptosis. [Diabetologia (1998) 41:249-256]

Keywords Apoptosis, proinsulin, umbilical vein, endothelial cells
Several lines of evidence suggest that endothelial dysfunction and damage present early steps in the pathophysiology of vascular complications in diabetes mellitus [1-3]. Several studies using cultured endothelial

Received: 15 July 1997 and in revised form: 6 October 1997

Corresponding author: Prof. Dr. P. Rösen, Diabetesforschungsinstitut, Auf'm Hennekamp 65, D-40225 Düsseldorf, Germany Abbreviations: PAI-1, Plasminogen activator inhibitor-1; NO, nitric oxide; ECGF, endothelial cell growth factor; BIM 1, bisindolylmaleimide-1; PMA, phorbol 12-myristate 13-acetate; PBS, phosphate buffered saline; ROI, reactive oxygen intermediates; 3-0-MG, 3-0-methyl-glucose; HUVECs, human umbilical vein endothelial cells; FACS, fluorescence activated cell sorter; BSA, bovine serum albumin; TUNEL, TdT-mediated dUTP nick end labelling; PKC, protein kinase C. cells clearly show that incubation of these cells with high concentrations of glucose leads to severe changes in the proliferation, the adhesive and synthetic properties [1]. Consequently, regulation of vascular relaxation by endothelium becomes disturbed in diabetes $[2,3]$. In addition to glucose, high concentrations of proinsulin have been shown to promote the synthesis of the plasminogen activator inhibitor type-1 (PAI-1) [4]. This observation indicates that endothelial function can be directly influenced not only by glucose, but also by proinsulin. Thus, high proinsulin levels may contribute to the development of vascular complications in diabetes, if secreted excessively. In line with this assumption proinsulin is increased in the late pre-insulin-dependent diabetes mellitus [5] and especially in non-insulin-dependent diabetic patients with abnormal prohormone convertase PC2 and PC3 activity [6] or with a point mutation in the 
coding region of the insulin gene allele [7]. Thus, an accumulation of partly damaged and dysfunctional cells has to be expected in the vasculature in diabetic conditions, which could rapidly lead to severe vascular defects in the regulation of vasomotion and thromboresistance. Slowly proliferating cells such as endothelial cells may be particularly affected by these pathophysiological alterations. Induction of apoptosis or programmed cell death [8] could represent one mechanism to eliminate the damaged cells, to prevent the fixation of vascular defects in these cells and to delay the development of vascular complications in diabetes. On the other hand, endothelial cell death and loss of functional endothelium is associated with a reduced thromboresistance of the vessel wall and may be one important factor to enhance the thrombogenic risk of diabetic patients. Not surprisingly, induction of apoptosis by glucose has recently been reported [9]; however, data about the influence of proinsulin are still missing.

The mechanisms by which glucose induces apoptosis are not yet well understood. Recent evidence suggests that PKC not only stimulates cell differentiation and proliferation, but might be also involved in inducing apoptosis [10]. In line with this assumption, it has been shown that stimulation of PKC by phorbolesters inhibits the induction of apoptosis induced by ceramide and nitric oxide (NO $[11,12]$. On the other hand, stauroporin, an often used inhibitor of PKC, has been shown to induce apoptosis [13] similarly to chelerythrine which increases the apoptotic fragmentation of DNA in a concentration dependent manner [14]. Similarly, in HL-60 cells DNA fragmentation induced by thapsgargin, and 4-bromo-calcium ionophore [15] was clearly inhibited by activation of PKC.

Apoptosis can also be induced by reactive oxygen species [16]. Since it has been shown that high glucose concentrations accelerates the generation of reactive oxygen species and that diabetes is associated with increased oxidative stress $[17,18]$, it is intriguing to assume that reactive oxygen species also constitute the intercellular signal for induction of apoptosis in diabetes.

The aim of our study was therefore firstly to investigate the influence of high concentrations of glucose and proinsulin on the induction of apoptosis in human endothelial cells, and secondly to investigate the mechanisms which are involved in the induction of apoptosis by diabetes.

\section{Materials and methods}

Reagents: In situ cell death detection kit and endothelial cell growth factor (ECGF) were purchased from Boehringer (Mannheim, Germany). Bisindolylmaleimide I (BIM-I), phorbol 12-myristate 13-acetate (PMA), collagenase, proinsulin, fetal bovine serum, M199 medium, Dulbecco's phosphate buf- fered saline (PBS), superoxide dismutase (SOD from human erythrocytes), 3- $O$-methyl-glucose (3- $O \mathrm{MG}$ ), and all other reagents were obtained from Sigma (Munich, Germany).

Cell and culture conditions. Human umbilical vein endothelial cells (HUVECs) were isolated from human umbilical cords by collagenase treatment and cultured as previously described by Jaffe et al. [19]. In brief, veins were washed with $150 \mathrm{ml}$ PBS to remove blood. Then a solution $(10 \mathrm{ml})$ of $0.1 \%$ collagenase was injected into the vein. After incubation for $15 \mathrm{~min}$ at $37^{\circ} \mathrm{C}$, the veins were flushed. The cells were washed out and collected by centrifugation $(750 \mathrm{rev} / \mathrm{min}$ for $10 \mathrm{~min})$. The sedimented cells were resuspended in M199-medium containing $20 \%$ fetal calf serum, $0.02 \%$ ECGF, $15 \mathrm{mmol} / 1$ Hepes, $2 \mathrm{mmol} / \mathrm{l}$ glutamine, $100 \mu \mathrm{g} / \mathrm{ml}$ each of streptomycin and penicillin and plated on $25 \mathrm{~cm}^{2}$ flasks after adjusting the number of cells to $1 \times 10^{5} / \mathrm{ml}$. After the cell layer became confluent (at $37^{\circ} \mathrm{C}, 5 \% \mathrm{CO}_{2}, 95 \%$ air), subcultures were performed using trypsin-EDTA $(0.125-0.2 \% 1: 1, \mathrm{v} / \mathrm{v})$. For all experiments cells from the 4th passage were used as individual isolates. Medium 199 containing $20 \%$ fetal calf serum was also used for incubation of cells under experimental conditions (high and low glucose, proinsulin, 3-O MG).

DNA fragmentation assay: DNA was extracted from $2 \times 10^{6}$ HUVECs as described by Fabio [20] with small modifications. In brief, HUVECs were suspended in PBS, and centrifuged at $750 \mathrm{rev} / \mathrm{min}$ for $10 \mathrm{~min}$. Then the pellet of cells was transferred into tubes with PBS, washed twice with cold PBS, and lysed with $10 \mathrm{mmol} / 1$ Tris $(\mathrm{pH} 7.5), 1 \mathrm{mmol} / 1$ EDTA, and $0.2 \%$ Triton $\mathrm{X}-100$. After incubation on ice for $15 \mathrm{~min}$, proteinase $\mathrm{K}$ (20 U) was added, and the samples were shaken overnight at $42^{\circ} \mathrm{C}$. Low and high molecular weight DNAs were separated by centrifugation at $13000 \times g$ at $4^{\circ} \mathrm{C}$ for $30 \mathrm{~min}$. Low molecular weight DNA in the supernatant was sequentially extracted by equal volumes of phenol, phenol : chloroform $(25: 24)$, and chloroform. The low molecular weight DNA was precipitated with two volumes of cold ethanol containing $\mathrm{NaCl}$ ( $1 \mathrm{~mol} / \mathrm{l}, 1 / 3$ volume) at $-80^{\circ} \mathrm{C}$ overnight. The DNA pellet was then obtained by centrifugation $\left(30 \mathrm{~min}\right.$ at $\left.4{ }^{\circ} \mathrm{C}\right)$ and washed with $70 \%$ ethanol. The pellet was dissolved in TE-Buffer (10 mmol/1 Tris-HCl, $\mathrm{pH}$ 8.0, $1 \mathrm{mmol} / \mathrm{l}$ EDTA $\mathrm{pH}$ 8.0), and analysed by agarose gel-electrophoresis $(1.8 \%$ gel) with ethidium bromide $(5 \mu \mathrm{g} / \mathrm{ml})$.

Fluorescence activated cell sorter (FACS) analysis. HUVECs were detached by incubation with $0.1 \%$ trypsin, centrifuged, washed twice with PBS, and stained by fluorescein as described by the manufacturer's protocol. Briefly, cells were washed twice in PBS containing $1 \%$ bovine serum albumin (BSA) and fixed cells by $4 \%$ paraformaldehyde in PBS for 30 min at room temperature. After washing the cells with PBS, cells were permeabilized for 2 min on ice by $0.1 \%$ Triton X-100 in $0.1 \%$ sodium citrate. To determine the number of single strand beaks of DNA we used the TUNEL method (TdT-mediated dUTP nick end labelling) to label the 3'-OH groups of DNA by fluorescein-dUTP (nick-end labelling). After two washes with PBS, cells were resuspended in $50 \mu \mathrm{l}$ of TUNEL reaction mixture containing deoxynucleotidyltransferase and fluorescein-dUTP and incubated for $60 \mathrm{~min}$ at $37^{\circ} \mathrm{C}$. Thereafter, cells were washed twice and analysed by flow cytometry (FACSStar, Becton \& Dickinson, Heidelberg, Germany).

In a parallel setting, cells were analysed by Laser Confocal Electron Microscopy (Acas Ultima 212; Meridin, Tokyo, Japan). The DNA labelling was performed similar to flow cytometry, with the exception that the cells were grown on glass slides. 


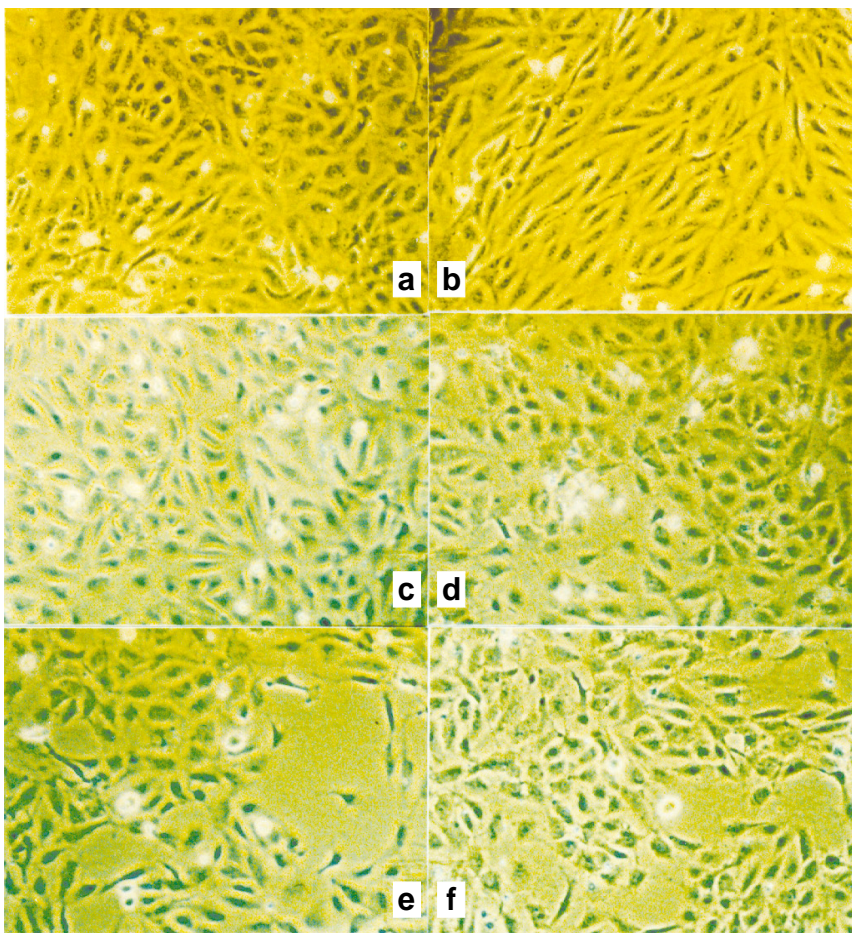

Fig. 1a-f. Influence of glucose and PKC activity on the morphology of cultivated HUVECs. Endothelial cells were isolated and cultivated as described in Methods. After 4th passage the cells were incubated for $72 \mathrm{~h}$ under the given conditions. Data from cells from an individual isolate are shown. The experiments were totally performed with cells from 3 individual cell isolates. a control ( $5 \mathrm{mmol} / \mathrm{l}$ glucose $)$; b PMA $(0.5 \mu \mathrm{mol} /$ 1 , activation of PKC); chigh glucose + PMA $(0.5 \mu \mathrm{mol} / 1)$; d BIM $(1.0 \mu \mathrm{mol} / \mathrm{l}$, inhibition of $\mathrm{PKC})$; e high glucose (30 mmol/l glucose); f high glucose + BIM

Morphology observation of apoptotic cells. After harvesting the cells with a cell screwper, morphology of the cells was performed by transmission electron microscopy (JEM2000-EX Japan, Jeol, Tokyo, Japan). Cells were fixed by being incubated with $2.5 \%$ glutaraldehyde for $4 \mathrm{~h}$. After several dehydrating steps samples were embedded and stained by uranylacetate.

Statistical analysis. Data are presented as mean \pm SD and were analysed by Student's $t$-test (Instat program; Graphpad, San Francisco, Calif., USA). For morphology and gel electrophoresis cells from 3 , for flow cytometry from 5 different isolates were used.

\section{Results}

Influence of proinsulin and glucose on apoptosis. Incubation of HUVECs with high concentrations of glucose $(30 \mathrm{mmol} / \mathrm{l})$ leads to time dependent alterations in the morphology of normal endothelial cells which are associated with the formation of apoptotic cells. First apoptotic cells can be detected after a $48 \mathrm{~h}$ incubation in high glucose concentrations. After $72 \mathrm{~h}$ most endothelial cells show severe alterations in the morphology which are typically seen in apoptotic cells. Even under the light microscope condensation

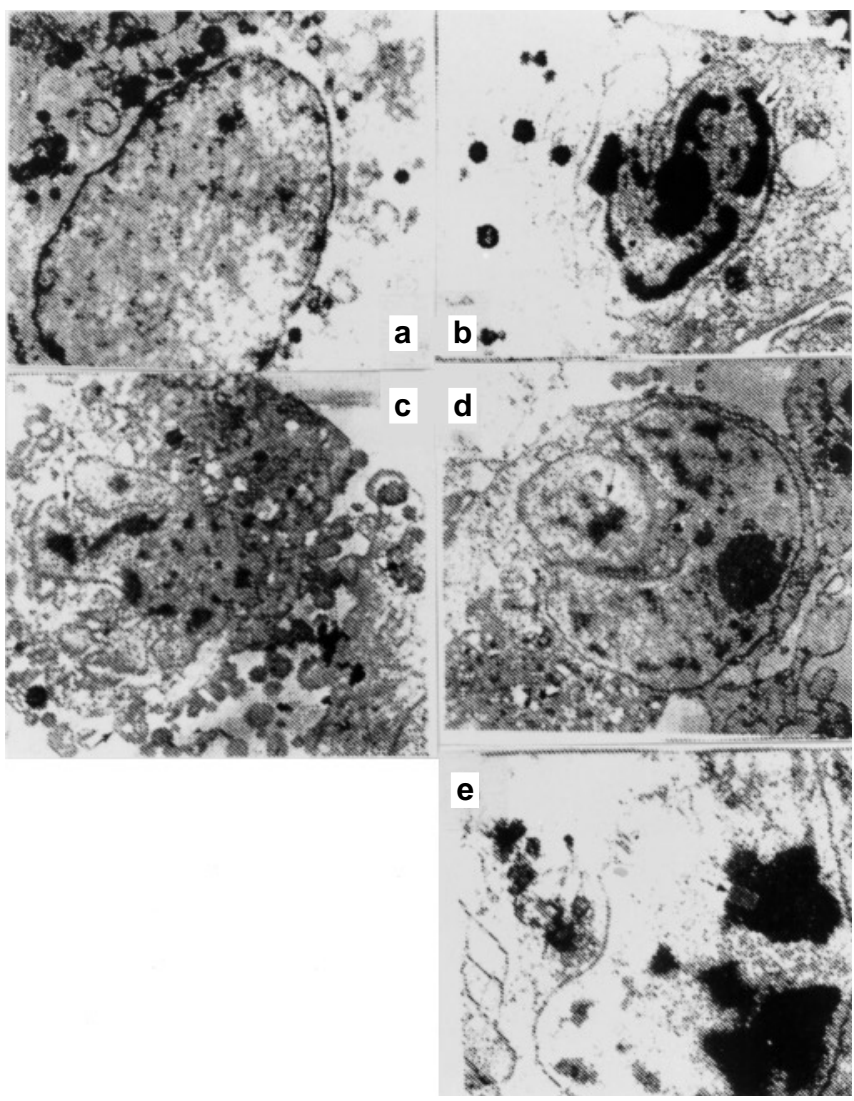

Fig. 2a-e. Electron microscopic observation of HUVECs after induction of apoptosis by incubation with $30 \mathrm{mmol} / 1$ glucose for $72 \mathrm{~h}$. a HUVECS incubated with low glucose $(5 \mathrm{mmol} / \mathrm{l}$ glucose) as control; b-d HUVECs after incubation with high glucose to induce apoptosis: condensation of chromatin (b), blebbing of cell membranes (c), formation of apoptotic bodies (d); e necrotic HUVECs with damaged cell membranes. Data from cells from an individual isolate are shown. The experiments were totally performed with cells from 3 individual cell isolates

and alterations in the typical cobblestone pattern of HUVECS can be seen (Fig. 1). After $72 \mathrm{~h}$ the endothelial monolayer is no longer tight and confluent. By losing cells, holes and interruptions in the endothelial monolayer arose (Fig. 1e,f). Similar changes were also observed after cultivation of endothelial cells with proinsulin (100 nmol/l, data not shown). As osmotic control we used $25 \mathrm{mmol} / \mathrm{l} \mathrm{D}$-mannitol (+ $5 \mathrm{mmol} / \mathrm{l} \mathrm{D}$-glucose). Under these conditions the number of apoptotic cells was not different from the low glucose controls.

By electron microscopy, several typical characteristics of apoptotic cells could be detected in endothelial cells incubated for $72 \mathrm{~h}$ with high glucose concentrations as compared to controls (Fig. 2 a): condensation of chromatin (b); fragmentation of the nucleus with the formation of small apoptotic bodies (c); cell shrinkage and blebbing of the plasma membrane (d). In contrast to apoptotic cells, in which the nuclear membranes were intact, these membranes were broken down in necrotic cells (Fig. 2e). Similar chan- 


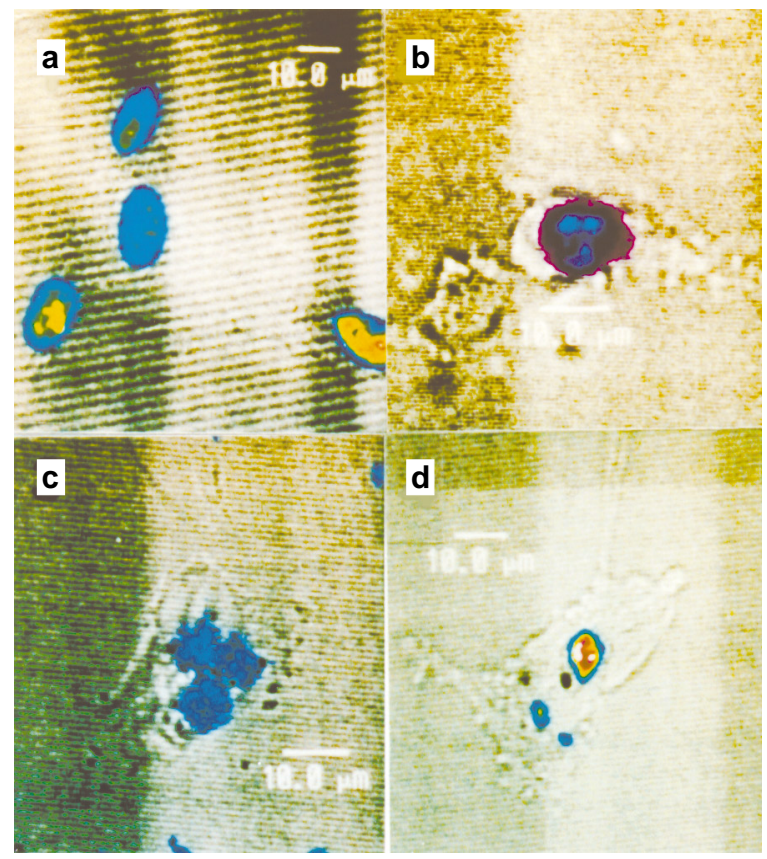

Fig. 3a-d. Laser confocal microscope of HUVECs incubated with $30 \mathrm{mmol} / 1$ glucose for $72 \mathrm{~h}$ to induce apoptosis. a HUVECs incubated with $5 \mathrm{mmol} / \mathrm{l}$ glucose (controls); b-d HUVECs incubated with $30 \mathrm{mmol} / \mathrm{l}$ glucose for $72 \mathrm{~h}$ to induce apoptosis: the nucleus is broken down (b), condensation of nucleus (c), beside the apoptotic cell, there is a non-apoptotic control cell not stained (d). Data from cells from an individual isolate are shown. The experiments were totally performed with cells from 3 individual cell isolates

ges were observed after cultivation of endothelial cells with proinsulin $(100 \mathrm{nmol} / \mathrm{l})$, data not shown).

When observed by confocal laser microscopy, the nuclei were evenly stained by fluorescein in controls (Figs. 3a). After incubation with high concentrations of proinsulin and glucose the situation was quite different. The chromatin was divided and several small DNA containing bodies (apoptotic bodies) could be distinguished (Fig. 3, b,c). Similar changes were observed if cells were incubated with high concentrations of proinsulin $(100 \mathrm{nmol} / \mathrm{l})$ for $72 \mathrm{~h}$.

Direct evidence for fragmentation of the nuclear DNA by the diabetogenic incubation was derived by agarose gel electrophoresis (Fig.4). In contrast to controls $(5 \mathrm{mmol} / 1$ glucose, no proinsulin, lane 4$)$, in which no DNA fragments could be detected in the gel, DNA of HUVECs incubated with high concentrations of glucose or proinsulin showed a typical DNA "ladder" in the range of 100 to about $2000 \mathrm{bp}$ (Fig. 4, lanes 3 and 7).

In line with the results of gel electrophoresis are data obtained by cytoflowmetry, a method by which the number of apoptotic cells can be directly quantified (Table 1). As can be seen, the number of apoptotic cells was increased by high glucose and proinsulin to about 351 and $336 \%$, respectively (controls taken as $100 \%$ ).

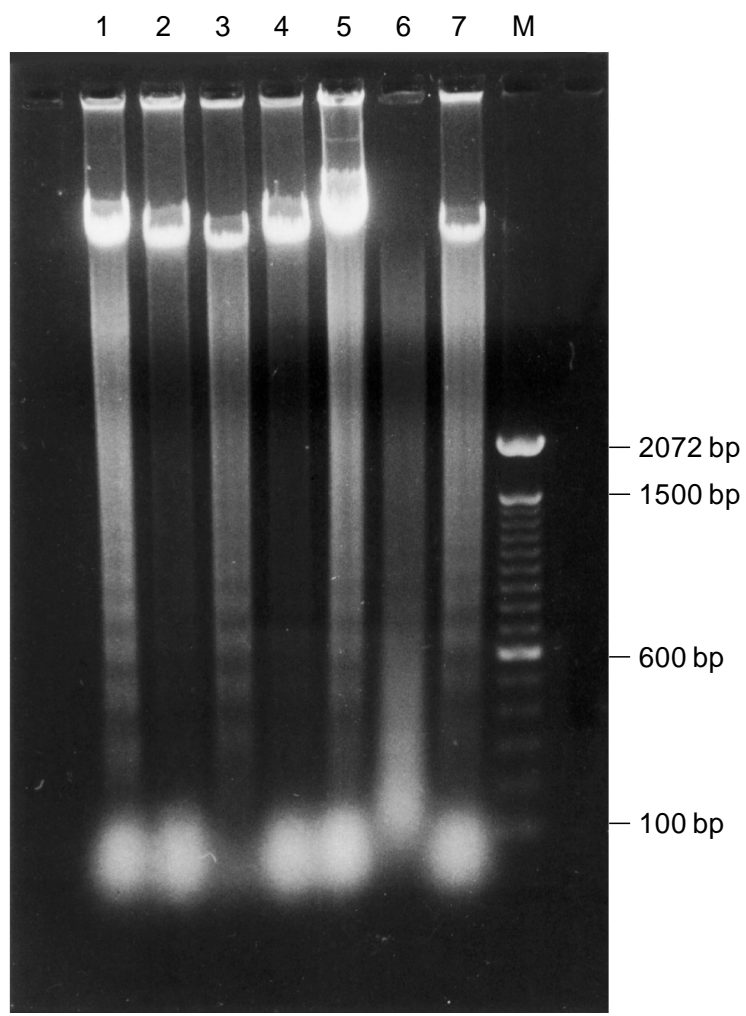

Fig. 4. Gel-electrophoresis of DNA extracted from HUVECs incubated with $30 \mathrm{mmol} / \mathrm{l}$ glucose or proinsulin for $72 \mathrm{~h}$ to induce apoptosis: Fragmentation of DNA. HUVECS were incubated with high glucose and proinsulin in the given concentrations for $72 \mathrm{~h}$ to induce apoptosis. Thereafter, the DNA was extracted and analysed by gelelectrophoresis as described. The data shown represent DNA fragmentation patterns in cells from an individual isolate. The experiments were totally done with cells from three individual isolates. Lanes: 1: high glucose (30 mmol/l glucose) with BIM; 2: high glucose with PMA $(1 \mu \mathrm{mol} / \mathrm{l}) ; 3$ : high glucose $(30 \mathrm{mmol} / \mathrm{l}$ glucose $) ; 4$ : control (5 mmol/l glucose); 5: proinsulin (100 nmol/l) with BIM; 6: proinsulin (100 nmol/l) with PMA; 7: proinsulin (100 nmol/ 1); M: marker of DNA ladder, the difference in size between two bands is $100 \mathrm{bp}$

Influence of protein kinase C. Stimulation of HUVECs by PMA $(0.5 \mu \mathrm{mol} / \mathrm{l})$ or inhibition by BIM $(1 \mu \mathrm{mol} / \mathrm{l})$ only slightly affected the number of apoptotic cells in the presence of low concentrations of glucose. Induction of apoptosis by high concentrations of glucose and proinsulin was, however, largely prevented if PKC was stimulated by the incubation of the cells with PMA (1 $\mu \mathrm{mol} / 1$, Fig. 4, lanes 2 and 6). On the other hand, inhibition of PKC in HUVECS by BIM $(0.5 \mu \mathrm{mol} / 1$, Fig. 4 , lanes 1 and 5) further increased the fragmentation of DNA. This conclusion is supported by FACS analysis. BIM stimulated the formation of apoptotic cells up to 505 and $491 \%$ of the control value and thus was more than observed by high glucose or proinsulin alone. Addition of PMA and activation of PKC, on the other hand, clearly reduced the number of cells in which apoptosis was 
Table 1. Influence of glucose, proinsulin, and $\mathrm{PKC}$ on the induction of apoptosis in HUVECs as determined by cytoflowmetry

\begin{tabular}{lccc}
\hline & \multicolumn{2}{l}{ Number of apoptotic cells (\% of total) } \\
\cline { 2 - 4 } & $3.1 \pm 0.5$ & $11.9 \pm 1.4$ & $14.5 \pm 1.0$ \\
\hline $\begin{array}{l}\text { Control } \\
(5 \mathrm{mmol} / \mathrm{l})\end{array}$ & $32.3 \pm 2.0^{\mathrm{a}}$ & $13.5 \pm 2.7^{\mathrm{b}}$ & $42.9 \pm 4.3^{\mathrm{b}}$ \\
$\begin{array}{l}\text { High glucose } \\
(30 \mathrm{mmol} / \mathrm{l})\end{array}$ & $28.6 \pm 2.0^{\mathrm{a}}$ & $13.0 \pm 1.2^{\mathrm{b}}$ & $41.7 \pm 3.6^{\mathrm{b}}$ \\
$\begin{array}{l}\text { Proinsulin } \\
(100 \mathrm{nmol} / \mathrm{l})\end{array}$ & & \\
\hline
\end{tabular}

Data are mean \pm SD

Each set of experiments was performed with cells from 5 individual isolates which are regarded as one cell-line.

${ }^{a} \mathrm{p}<0.05 \pm$ high glucose or proinsulin;

b $\mathrm{p}<0.05 \pm$ PMA or BIM, respectively

induced (+ 159 and $153 \%$ of controls), but did not completely prevent induction of apoptosis.

Influence of superoxide and dismutase 3-OMG. To test whether induction of apoptosis is dependent on glucose itself or on a metabolite of glucose conversion, HUVECs were incubated with 3-OMG instead of high concentrations of glucose $(5 \mathrm{mmol} / \mathrm{l}$ gluco$\mathrm{se}+25 \mathrm{mmol} / \mathrm{l} 3-\mathrm{OMG})$. The number of apoptotic cells was determined by FACS-analysis (Fig. 5). It can be clearly seen that incubation of HUVECs with 3-OMG (25 mmol/1 3-OMG + $5 \mathrm{mmol} / \mathrm{l}$ glucose) led to a shift in the mean fluorescence to higher values indicating an increased number of end-labelled DNAfragments. Whereas in controls $3.1 \%$ cells were identified as apoptotic, incubation with glucose $(30 \mathrm{mmol} /$ 1) and 3-OMG $(5 \mathrm{mmol} / \mathrm{l}$ glucose $+25 \mathrm{mmol} / \mathrm{l} 3$ $\mathrm{OMG}$ ) increased the number of apoptotic cells up to 32 and $39 \%$, respectively (Table 1 ). This observation is in line with data obtained by gel electrophoresis (Fig.6). High glucose concentrations (lane 3) and 3OMG (lanes 5 and 6), both caused a DNA laddering as compared to controls incubated with $5 \mathrm{mmol} / \mathrm{l} \mathrm{glu}-$ cose (lane 4).

To examine whether superoxide anions are involved in the process of DNA fragmentation, the cells were exposed to high concentrations of glucose $(30 \mathrm{mmol} / \mathrm{l})$ or $3-\mathrm{OMG}(25 \mathrm{mmol} / \mathrm{l}+5 \mathrm{mmol} / \mathrm{l} \mathrm{glu}-$ cose) in the presence of superoxide dismutase $(100 \mu \mathrm{g} / \mathrm{ml})$. Thereafter the DNA was extracted and analysed by gel electrophoresis. Whereas superoxide dismutase did not influence the DNA fragmentation pattern in low glucose controls, it totally prevented the formation of DNA fragments in cells incubated in high glucose of high 3-OMG concentrations (Fig. 6, lanes 2 and 5). To get a quantitative measure of this inhibitory effect of superoxide dismutase, DNA fragmentation was also studied by the TUNEL method and analysed by flow cytometry. High glucose or 3-OMG concentrations shifted the mean fluores-
V3: 100497020\FL1-H\FL1-Height

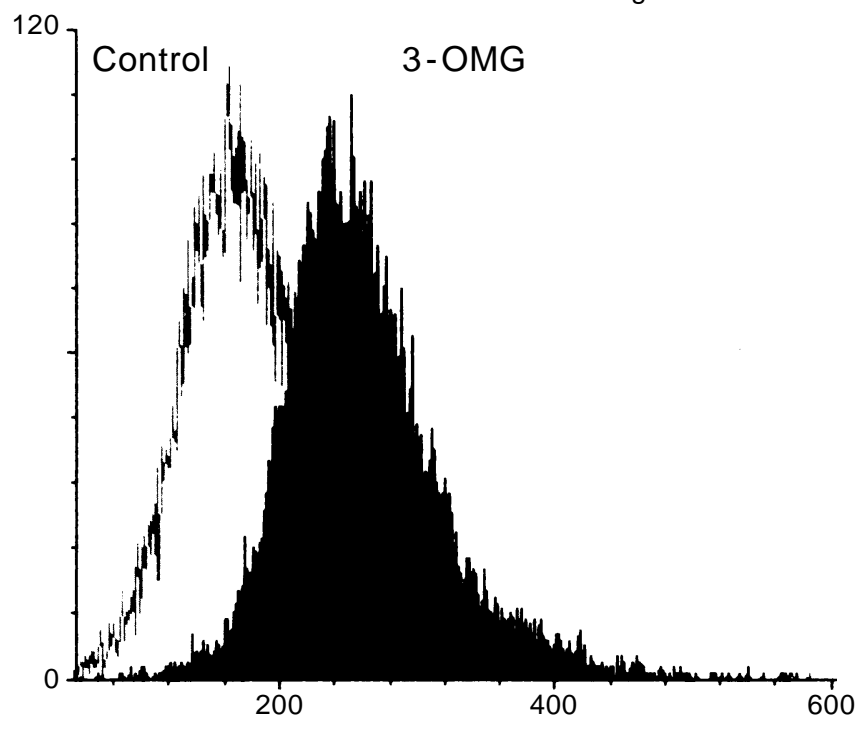

V3: 100497014\FL1-H\FL1-Height

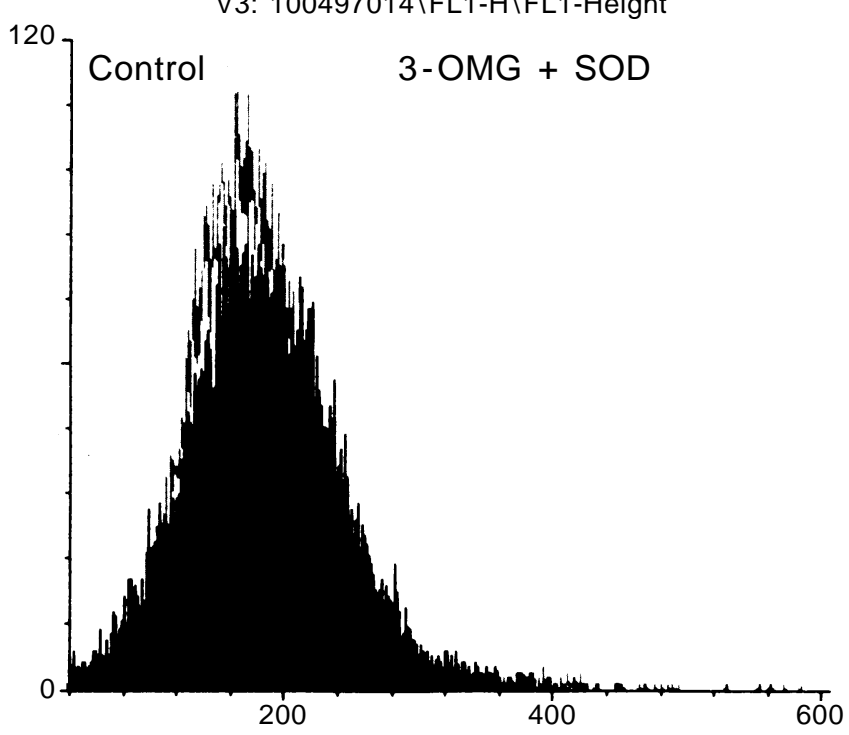

Fig. 5. Influence of high hyperglycaemic concentrations of 3OMG on the amount of apoptotic cells analysed by FACS. HUVECs were cultivated for $72 \mathrm{~h}$ with glucose $(5 \mathrm{mmol} / \mathrm{l})$ or with $3-\mathrm{OMG}(5 \mathrm{mmol} / \mathrm{l}$ glucose $+25 \mathrm{mmol} / \mathrm{l} 3-\mathrm{OMG})$ to induce apoptosis. In parallel cells were incubated with 3-OMG plus SOD $(100 \mu \mathrm{g} / \mathrm{ml})$. After incubation the cells were stained for DNA fragments by the TUNEL method as described in Methods. Data from cells from an individual isolate are shown. The experiments were totally done with cells from 5 individual cell isolates

cence intensity to higher levels indicating an increase in the number of cells with fragmented DNA. In the presence of superoxide dismutase this shift was nearly completely prevented (Fig. 5). Accordingly, the number of apoptotic cells was no longer different as compared to low glucose controls (Table 2). 


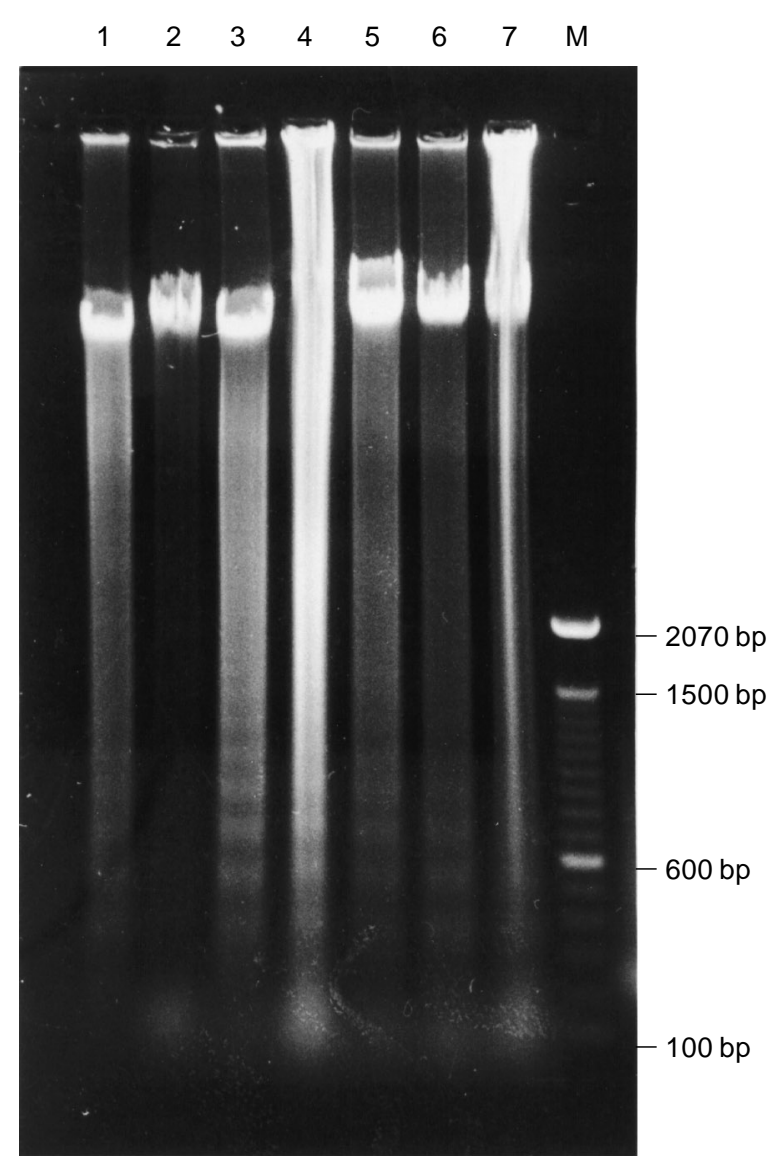

Fig. 6. Influence of incubation of HUVECs with 3-OMG and SOD on DNA fragmentation. HUVECS were incubated with glucose or 3-OMG in the given concentrations for $72 \mathrm{~h}$ to induce apoptosis. In parallel, identical samples were treated with SOD. Thereafter, the DNA was extracted and analysed by gel-electrophoresis as described. Data from cells from an individual isolate are shown. The experiments were totally performed with cells from 3 individual cell isolates. Lanes: 1: control $(5.0 \mathrm{mmol} / \mathrm{l}$ glucose $) ; 2$ : control + SOD $(100 \mu \mathrm{g} / \mathrm{ml})$; 3: high glucose $(30 \mathrm{mmol} / \mathrm{l})$; 4 : high glucose + SOD $(100 \mu \mathrm{g} /$ $\mathrm{ml})$; 5 and 6: high 3-OMG (25 mmol/1 3-OMG + $5 \mathrm{mmol} / \mathrm{l} \mathrm{glu}-$ cose); 7: high 3-OMG + SOD $(100 \mu \mathrm{g} / \mathrm{ml})$

\section{Discussion}

The studies performed here provide evidence that incubation of HUVECs with high concentrations of glucose or proinsulin can induce apoptosis. Evidence for this is obtained by three different methods - fragmentation of DNA into oligosomal length fragments of DNA as shown by gel electrophoresis (Fig. 4 and $[6,21])$, - FACS-analysis using the TdT-mediated dUTP nicked labelling technique (TUNEL [22]), which allows the labelling of double stranded DNA breaks (Fig. 5), - and morphological data suggesting the integrity of the plasma membrane and the formation of apoptotic bodies (Fig. 1).

The number of spontaneously apoptotic cells observed under normal cell culture conditions ( $5 \mathrm{mmol} / \mathrm{l}$ glucose) was low as shown by previously
Table 2. Influence of superoxide dismutase (SOD) on the induction of apoptosis in HUVECs by glucose or 3-O-methylglucose (3-OMG) as determined by cytoflowmetry

\begin{tabular}{llc}
\hline & \multicolumn{2}{l}{ Number of apoptotic cells (\% of total) } \\
\cline { 2 - 3 } & - SOD & + SOD \\
\hline $\begin{array}{l}\text { High glucose } \\
(30 \mathrm{mmol} / \mathrm{l})\end{array}$ & $32.3 \pm 2.0$ & $11.6 \pm 1.1^{\mathrm{a}}$ \\
$3-\mathrm{OMG}$ & $39.2 \pm 1.2$ & $8.7 \pm 0.9^{\mathrm{a}}$ \\
$(25 \mathrm{mmol} / \mathrm{l})$ & & \\
\hline
\end{tabular}

Data are mean \pm SD

Each set of the experiments was performed with cells from 5 individual isolates which are regarded as one cell line. ${ }^{\mathrm{a}} \mathrm{p}<0.05 \pm \mathrm{SOD}$

published data $[9,23]$ indicating that isolation and cultivation of the cells did not damage them irreversibly and induced apoptosis thus confirming the homogeneity and quiescence of the cells under our culture conditions. That high glucose concentrations can induce apoptosis has already been shown by Baumgartner-Parzer et al. [9]. Data published by Lorenzi et al. [24-26] show that high glucose interferes with the regulation of cell cycle and leads to a delayed proliferation of HUVECs. These authors suggested that high glucose retards the cell cycle transition from the $\mathrm{S}$ and $\mathrm{G} 2$ phases. In addition, they presented evidence that high glucose is able to accelerate the unwinding of DNA which is indicative of an increase of single strand breaks and may be one cause of the observed accelerated cell death of endothelial cells in hyperglycaemia [25, 26]. It is not clear whether the described changes are a consequence of an induction of apoptosis or represent additional processes leading to a damage of endothelium by hyperglycaemia.

The mechanisms by which high concentrations of glucose can induce apoptosis are not yet understood. There is some evidence that high glucose can lead to an increased formation of diacylglycerol and thereby, to an activation of protein kinase [27, 28]. Furthermore, several authors have described that protein kinase $\mathrm{C}$ (PKC) may be involved in regulation of apoptosis [10-15], although the direction of the effect varies in the different types of cells. In contrast to our assumption, activation of PKC by phorbolesters inhibited the formation of apoptotic cells, whereas inhibition of PKC further augmented the number of apoptotic cells. Thus, in HUVECs induction of apoptosis by high glucose concentrations or proinsulin is not mediated by an activation of PKC. A similar inhibitory effect of PKC activation on apoptosis has also been described in other cells such as macrophages [10]. It has to be taken into consideration, however, that the role of PKC varies in different cell types and that the observations reported here for HUVECs are not necessarily valid for other cell systems [10$15]$. 
Interestingly, apoptosis was also induced to a similar extent by glucose as by incubation with 3-OMG. This glucose analogue is taken up by the cells and phosphorylated, but not further metabolised. This strongly suggests that it is not the conversion of glucose to metabolic intermediates downstream of the phosphorylation of glucose by hexokinase and the production of diacylglycerol which mediates the intracellular signal for the induction of apoptosis, but glucose or a metabolite formed independently from the glycolytic pathway. That apoptosis is induced by a glucose analogue which cannot enhance the formation of diacylglycerol, and that activation of PKC does not cause an increase in the amount of apoptotic cells, clearly exclude an involvement of PKC as a necessary step for induction of apoptosis by glucose or proinsulin.

Both processes, induction of apoptosis by glucose and by 3-OMG, were completely inhibited in the presence of superoxide dismutase. Thus, it is reasonable to assume that superoxide anions are involved in the signalling process. That apoptosis can be induced by reactive oxygen species such as superoxide anions, hydrogen peroxides and other reactive oxygen species is well supported by experimental evidence [16]. On the other hand, it is also known that endothelial cells generate reactive oxygen intermediates (ROI) under hyperglycaemic conditions [29-32]. This conclusion is also supported by recent results in which the release of superoxide anions has been directly measured under the same conditions which cause the induction of apoptosis $(30 \mathrm{mmol} / \mathrm{l}$ glucose, $72 \mathrm{~h}$, $10 \%$ FCS) (Rösen et al., unpublished results). Thus, our data suggest that by incubation with high concentrations of glucose, superoxide anions are generated and these superoxide anions are part of the intracellular signalling pathway leading to the induction of apoptosis by glucose or proinsulin.

The mechanisms causing an increased formation of ROI and especially superoxide anions is not yet fully understood and several mechanisms have been suggested. Graier et al. [29] suggested an enhanced formation of superoxide anions due to metal-catalysed oxidation of glucose in endothelial cells. This mechanism could also explain why 3-OMG is as effective as glucose in the stimulation of the formation of superoxide anions. On the other hand, there are several lines of evidence to show that the intracellular generation of glycation products is strictly coupled to the production of ROI [30] and that advanced glycation endproducts are able to induce the production of ROI by an activation of the receptor for advanced glycosilation endproducts (RAGE) [31]. The formation of prostaglandin endoperoxides might represent another source for the generation of ROI as outlined by Tesfamariam [32]. Finally there is some evidence that the electron flow in the NO-synthase complex is not very tightly coupled at least under some experimental conditions. The activation of NO-synthase by elevated intracellular calcium levels [26] might cause the escape of ROI from the NO-synthase complex (Rösen, unpublished data).

That ROI can induce apoptosis has already been clearly shown [16]; however, the exact molecular mechanism is not yet understood. If we assume that in most cells apoptosis is a process which requires energy as well as de novo gene transcription and protein synthesis [33,34], it is intriguing to suggest that changes in gene expression mediated by activation of transcription factors such as a nuclear transcription factor $x \mathrm{~B}(\mathrm{NF} x \mathrm{~B})$ [34] may play an important role. We have preliminary evidence for activation of $\mathrm{NF} x \mathrm{~B}$ under our experimental conditions (Rösen, unpublished data), but it has been shown by others [35,36], that several forms of oxidative stress can activate NFxB and stimulate various NFxB mediated processes.

In summary, we present evidence that diabetogenic conditions induce apoptosis in HUVECs and that this process is presumably strictly dependent on the formation of reactive oxygen species. The induction of apoptosis might represent a surviving mechanism for vascular cells in diabetes, to eliminate severely damaged cells and to retain the functional integrity of the vascular wall for some time and to delay the development of vascular complications which is a timeconsuming process. Thus, induction of apoptosis may contribute to limiting the damage of the vasculature by reactive oxygen species generated in excess in diabetes.

Acknowledgements. This work was supported by the Ministerium für Frauen, Familie und Gesundheit der Bundesrepublik Deutschland and the Wissenschaftsministerium des Landes NRW, the Deutsche Forschungsgemeinschaft, Bonn, and the "Klinische Zellbiologie und Biophysik" e. V., Düsseldorf.

\section{References}

1. Lorenzi M, Cagliero E (1991) Pathobiology of endothelial and other vascular cells in diabetes mellitus. Diabetes 40: 653-659

2. Cohen RA (1993) Dysfunction of vascular endothelium in diabetes mellitus. Circulation 87 [Suppl 5]: 67-76

3. Rösen P, Ballhausen Th, Bloch W, Addicks K (1995) Endothelial relaxation is disturbed in the diabetic rat by oxidative stress: the influence of tocopherol as antioxidant. Diabetologia, 38: 1157-1168

4. Nordt TK, Schneider DJ, Sobel BE (1994) Augmentation of the synthesis of plasminogen activator inhibitor type-1 by a precursor of insulin. Circulation 89: 321-330

5. Rodriguez-Villar C, Conget I, Casamitjama R, Vidal J, Manzanares JM, Gomis R (1997) High proinsulin levels in late pre-IDDM stage. Diabetes Res Clin Pract 37: 145-148

6. Haffner SM, Stern MP, Mittinen H (1995) High proinsulin and specific insulin are both associated with a parental history of diabetes in non-diabetic Mexican-American subjects. Diabetes 44: 1156-1160

7. Sanke T, Nanjo K (1994) Review for clinical molecular genetics of mutant insulin. Nippon Rinsho 52: 2550-2555 
8. Kerr JFR, Wyllie AH, Currie AR (1972) Apoptosis: a basic biological phenomenon with wide-ranging implications in tissue kinetics. Br J Cancer 26: 239-257

9. Baumgartner-Parzer SM, Wagner L, Pettermann M, Grillari J, Gessl A, Waldhäusl (1995) High-glucose-triggered apoptosis in cultured endothelial cells. Diabetes 44: 1323 1327

10. Munn DH, Beall AC, Song D, Wrenn RW, Throckmorton DC (1995) Activation-induced apoptosis in human macrophages: developmental regulation of a novel celldeath pathway by macrophage-colony-stimulating factor and interferon-gamma. J Exp Med 181: 127-136

11. Hannun YA, Obeid LM (1995) Ceramide: an intracellular signal for apoptosis. Trends Biochem Sci 20: 73-77

12. Messmer UK, Lapetina EG, Brune B (1995) Nitric oxideinduced apoptosis in RAW-254.7 macrophages is antagonised by protein-kinase-A-activating compounds. Mol Pharm 47: 757-765

13. Jacobson MD, Burne JF, King MP, Miyashita T, Reed JC, Raff MC (1993) Bcl-2 blocks apoptosis in cells lacking mitochondrial DNA. Nature 361: 365-369

14. Jarvis WD, Turner AJ, Povirk LF, Traylor RS, Grant S (1994) Induction of apototic DNA fragmentation and cell death in HL-60 human promyelocytic leukemia cells by pharmacological inhibitors of protein kinase C. Cancer Res 54: 1707-1714

15. Zhu WH, Loh TT (1996) Differential effects of phorbol ester on apoptosis in HL-60 promyelocytic leukemia cells. Biochem Pharmacol 51: 1229-1236

16. Powis G, Gasdaska JR, Baker A (1997) Redox signaling and the control of cell growth and death. In: Sies H (ed) Antioxidants in disease: mechanisms and therapy. Academic Press, New York, pp 329-359

17. Hunt JV, Smith CT, Wolff SP (1990) Autoxidative glycosylation and possible involvement of peroxides and free radicals in LDL modification by glucose. Diabetes 39:14201424

18. Lyons TJ (1991) Oxidised low density lipoproteins: a role in the pathogenesis of atherosclerosis in diabetes? Diabet Med 8: 411-419

19. Jaffe FA, Hoyer LW, Nachman RL (1973) Synthesis of antihemophilic factor antigen by cultures human endothelial cells. J Clin Invest 52: 2757-2764

20. Fabio RC (1994) Inhibition of anchorage-dependent cell spreading triggers apoptosis in cultured human endothelial cells. J Cell Biol 127: 537-546

21. Martin SJ, Green DR, Cotter TG (1994) Dicing with death: dissecting the components of the apoptosis mechanisms. TIBS 19: 26-30

22. Philgreen M, Thomas J, Marvel J (1996) Comparison of two cell death detection methods: in situ nick translation and TUNEL. Boehringer Information 99: 13-14
23. Polunovsky VA, Wendt $\mathrm{CH}$, Ingbar DH, Peterson MS, Bittermann PB (1994) Induction of apoptosis by TNFa: modulation by inhibitors of protein synthesis. Exp Cell Res 214: 584-594

24. Lorenzi M, Cagliero E, Toledo S (1985) Glucose toxicity for human endothelial cells in culture. Delayed replication, disturbed cell cycle and accelerated death. Diabetes 34: 621-627

25. Lorenzi M, Montisano DF, Toledo S, Barrieux A (1986) High glucose induces DNA damage in cultured human endothelial cells. J Clin Invest 77: 322-325

26. Lorenzi M, Nordberg JA, Toledo S (1987) High glucose prolongs cell-cycle traversal of cultured human endothelial cells. Diabetes 36: 1261-1267

27. Inoguchi T, Xia P, Kunisaki M, Higashi S, King GL (1994) Preferential elevation of protein kinase $\mathrm{C}$ isoform II and diacylglycerol levels in the aorta and heart of diabetic rats: differential reversibility of glycaemic control by islet cell transplantation. Proc Natl Acad Sci (USA) 89: 1105911063

28. Lee TS, MacGregor LC, Fluharty SJ, King GL (1989) Differential regulation of protein kinase $\mathrm{C}$ and $(\mathrm{Na}, \mathrm{K})$-adenosine triphosphate activities by elevated glucose levels in retinal capillary endothelial cells. J Clin Invest 83: 90-94

29. Graier WF, Simecek S, Kukovetz W, Kostner GM (1996) High glucose-induced changes in endothelial $\mathrm{Ca}^{2+} / \mathrm{EDRF}$ signaling are due to generation of superoxide anions. Diabetes 45: 1386-1395

30. Giardino I, Edelstein D, Brownlee M (1996) Bcl-2 expression or antioxidants prevent the hyperglycemia-induced formation of intracellular advanced glycation endproducts in bovine endothelial cells. J Clin Invest 97: 1422-1428

31. Yan SD, Schmidt AM, Anderson GM et al. (1994) Enhanced cellular oxidant stress by the interaction of advanced glycation end products with their receptors/binding proteins. J Biol Chem 269: 9889-9897

32. Tesfamariam B (1994) Free radicals in diabetic endothelial cell dysfunction. Free Radic Biol Med 16: 383-391

33. Sellins KS, Cohen JJ (1987) Gene induction by gamma-irradiation leads to DNA fragmentation in lymphocytes. $\mathrm{J}$ Immunol 139: 3199-3206

34. Wyllie AH (1980) Glucocorticoid-induced thymocytes apoptosis is associated with endogenous endonuclease activation. Nature 284: 555-556

35. Meyer M, Schreck R, Baeuerle PA (1993) $\mathrm{H}_{2} \mathrm{O}_{2}$ and antioxidants have opposite effects on activation of NF- $x \mathrm{~B}$ and AP-1 in intact cells: AP-1 as secondary antioxidant-responsive factor. EMBO J 12: 2005-2015

36. Higgins KA, Perez JR, Coleman TA et al. (1993) Antisense inhibition of the p65 subunit of NF- $x$ B blocks tumorgenicity and causes tumor regression. Proc Natl Acad Sci USA 90: 9901-9905 